\title{
Penja fish (Genus: Sicyopterus) from Karama River, West Sulawesi, Indonesia: Growth pattern and habitat characteristics
}

\author{
CUT MUTHIADIN ${ }^{1, \bullet}$, ISNA RASDIANAH AZIZ ${ }^{1}$, HASYIMUDDIN ${ }^{1}$, FATMAWATI NUR $^{1}$, ST. AISYAH SIJID ${ }^{1}$, \\ SAIFULLAH AZMAN ${ }^{1}$, RENNY KURNIA HADIATY ${ }^{2}$, ILHAM ALIMUDDIN ${ }^{3}$ \\ ${ }^{1}$ Department of Biology, Faculty of Science and Technology, Universitas Islam Negeri Alauddin Makassar. Jl. H.M. Yasin Limpo No. 36 Romangpolong, \\ Gowa 92113, South Sulawesi, Indonesia. Tel./fax.: +62-411-1500363, `email: cutmuthiadin@uin-alauddin.ac.id, isna-rasdianah@uin-alauddin.ac.id \\ ${ }^{2}$ Zoology Division, Research Center for Biology, Indonesian Institut of Sciences. Jl. Raya Jakarta Bogor Km. 46, Cibinong, Bogor 16911, West Java, Indonesia \\ ${ }^{3}$ Department of Geological Engineering, Faculty of Engineering, Universitas Hasanuddin. Jl. Poros Malino KM. 6, Bontomarannu, Gowa 92171, South \\ Sulawesi, Indonesia
}

Manuscript received: 6 August 2020. Revision accepted: 30 September 2020.

\begin{abstract}
Muthiadin C, Aziz IR, Hasyimuddin, Nur F, Sijid SA, Azman S, Hadiaty RK, Alimuddin I. 2020. Penja fish (Genus: Sicyopterus) from Karama River, West Sulawesi, Indonesia: Growth pattern and habitat characteristics. Biodiversitas 21: $4959-4966$. Sicydiinae gobies have been widely collected and identified throughout tropical Indo-Pacific, except in Karama River, Mamuju, West Sulawesi, Indonesia. Penja was the goby fish's local name, where their belly has the adhesive disc entirely formed by the pelvic fins. This study aims to describe the habitat and growth patterns of genus Sicyopterus in Karama river, which passes through three sub-districts. The research was conducted in Karama River from four sites: Kalumpang, Bonehau, Arassi, and Kalonding. Fish growth was described by Deroberts and William model, and continued with habitat characteristics. The total number of fish from four sites about 71 adults Sicyopterus species (family Gobiidae): Sicyopterus longifilis and Sicyopterus pugnans. The average growth pattern in all sites is isometric negative $(\mathrm{b}<3)$, except in the Kalumpang sites, growth pattern for S. longifilis is isometric $(\mathrm{b}=3)$ whereas in S. pugnans in the Kalumpang sites growth pattern is positive allometric $(b>3)$. The value of condition factor $(\mathrm{K})$ ranges between 1.89-2.28, it means the average shape of fish is flat. It is related to the average growth pattern from four sites that are allometric (growth of length more than the growth of weight). Nevertheless, the value of $\mathrm{Wr}$ in average 100, which describe that environment of fish is good, related from abiotic measurement in all site showed fit condition for Sicyopterus species habitat. Further studies will be focused on the food supply and predator of Sicyopterus.
\end{abstract}

Keywords: Goby fish, growth model, length-weight relationship, Sicyopterus longifilis, Sicyopterus pugnans

\section{INTRODUCTION}

Sicydiinae gobies have shown the highest level of diversity and endemism, classified as amphidromous fishes (Ebner et al. 2011; Keith et al. 2011) that migrates between freshwater and the ocean at different stages in their life cycle (Hoareau et al. 2012; Iida et al. 2013; Boseto et al. 2016) which critically on the integrity of the mountainlake-river-ocean corridor (Roche et al. 2013; Eagderi et al. 2018; Christoffersen et al. 2019). The migration plays an important role in their life cycle, including recruitment, growth, maturation, and reproduction (Ellien et al. 2014; Teichert et al. 2014). The larvae drift immediately downstream to the estuary (Iida et al. 2015), and after 2 to 6 months, the post-larvae migrate back into the rivers (Bauer 2013; Shiao et al. 2015; Olii et al. 2017; Tran et al. 2018). Besides hydro-ecological characteristics, highnutrient found in the estuary can cause a high abundance of phytoplankton that affects zooplankton and fish at the early life stage, including postlarvae, which acts as consumers (Bhaumik et al. 2011; Taillebois et al. 2012; Cloern 2018).

Trading of goby fish has been a common practice in traditional markets in the Indo-Pacific area. Gobies caught by fishermen using traps and nets are sold in traditional markets and consumed as alternative food in Philippines (Mahilum et al. 2013; Vedra and Ocampo 2014). In
Taiwan, Japan, China, and Thailand, local people consume gobies in soups and salads due to the delicacy and high nutritional value (Rojtinnakorn et al. 2012; You et al. 2015; Kachhi et al. 2020). Sicydiinae gobies in Indonesia are a typical food of West Sulawesi Province with various preparations (Gani et al. 2019; Nurjirana et al. 2019). The local community usually preserved these fishes by salting and sun-drying then sold them in the traditional and online markets.

Even though Sicydiinae gobies have been collected and identified from freshwater streams throughout the tropical Indo-Pacific, however, it still many islands of this region have never been collected. The lower, middle and upper reaches are the main inhabited part of rivers in the Pacific area by genus Sicyopterus (Ellien et al. 2011; Artzrouni et al. 2014; Keith et al. 2015). On the belly side of the body, these gobies bear the pelvic disc as an adhesive organ (Keith et al. 2014; Lord et al. 2019). The first observation of Sicyopterus species (Penja fish) in West Sulawesi was made by some fishermen. They found the juvenile was live in the river. Penja fish were identified as Sicyopterus species, and it was hypothesized that Penja fish would school with other species Awaous melanocephalus (Muthiadin et al. 2017).

Information about the existence of Sicypterus gobies is only obtained from fishermen and the local community. 
Further, there has been no record of Sicyopterus species from the selected river on the FishBase database. In this study, we aim to describe Sicyopterus species from Karama River, West Sulawesi, Indonesia, along with its growth patterns and morphological characteristic. This study would help improve fishery management strategies in Karama River in order to preserve biodiversity and protect sustainability while maintaining continuous harvesting for domestic and trade commercial.

\section{MATERIALS AND METHODS}

\section{Study area}

The research was conducted in Karama/Karana River, which passes through three sub-districts of Kalumpang, Bonehau, and Sampaga (Figure 1), Pangale District, Mamuju Regency, West Sulawesi Province, Indonesia in May, 2018with the rainy season. The location used by the fishermen as sampling point of Penja (Sicyopterus sp.). Sample found in four sites: Kalumpang, Bonehau, Arassi, and Kalonding.

\section{Procedures}

\section{Sampling procedure}

Sampling was conducted at four sites (Figure 1). The location used as a sampling point for Gobiidae fish was conducted with fishermen. The samples were caught using casting nets and temporary stored in each jar. The sampled specimens were preserved in $4 \%$ formalin and then transported to the Laboratory of Zoology, Universitas Islam Negeri Alauddin Makassar for further analysis.

\section{Physical data measurement}

Habitat characteristics, including the $\mathrm{pH}$, dissolved oxygen (DO), temperature, depth, current velocity, substrate type, salinity, altitude from sea level, and the growth pattern of the fish were recorded (Table 1).

\section{$L T$ and $L S$ measurement}

Dial vernier caliper (Tricle brand (®) was used to measure total length (LT) and standard length (LS) of the specimens to the nearest $0.02 \mathrm{~mm}$ and weight to the nearest $0.01 \mathrm{~g}$ (Kern KB3600) (Keith et al. 2015). The formula: $\mathrm{W}=\mathrm{a} L \mathrm{~T}^{\mathrm{b}}$ was applied to calculate the length-weight relationship, where $\mathrm{W}$ is weight in grams, LT is total length in centimeters, and $a$ and $b$ are regression coefficient and exponent, respectively (Greenfield and Randall 2010).

\section{Data analysis}

This research uses the long-weight relationship formula using the Linear Allometric Model (LAM) equation as an analysis of the sample to be observed based on DeRoberts and William (2008). $\mathrm{W}=\mathrm{aL}^{\mathrm{b}}$, which $\mathrm{W}=$ fish weight (grams), $\mathrm{L}=$ total length of fish $(\mathrm{mm})$, $\mathrm{a}$ and $\mathrm{b}$ parameters.
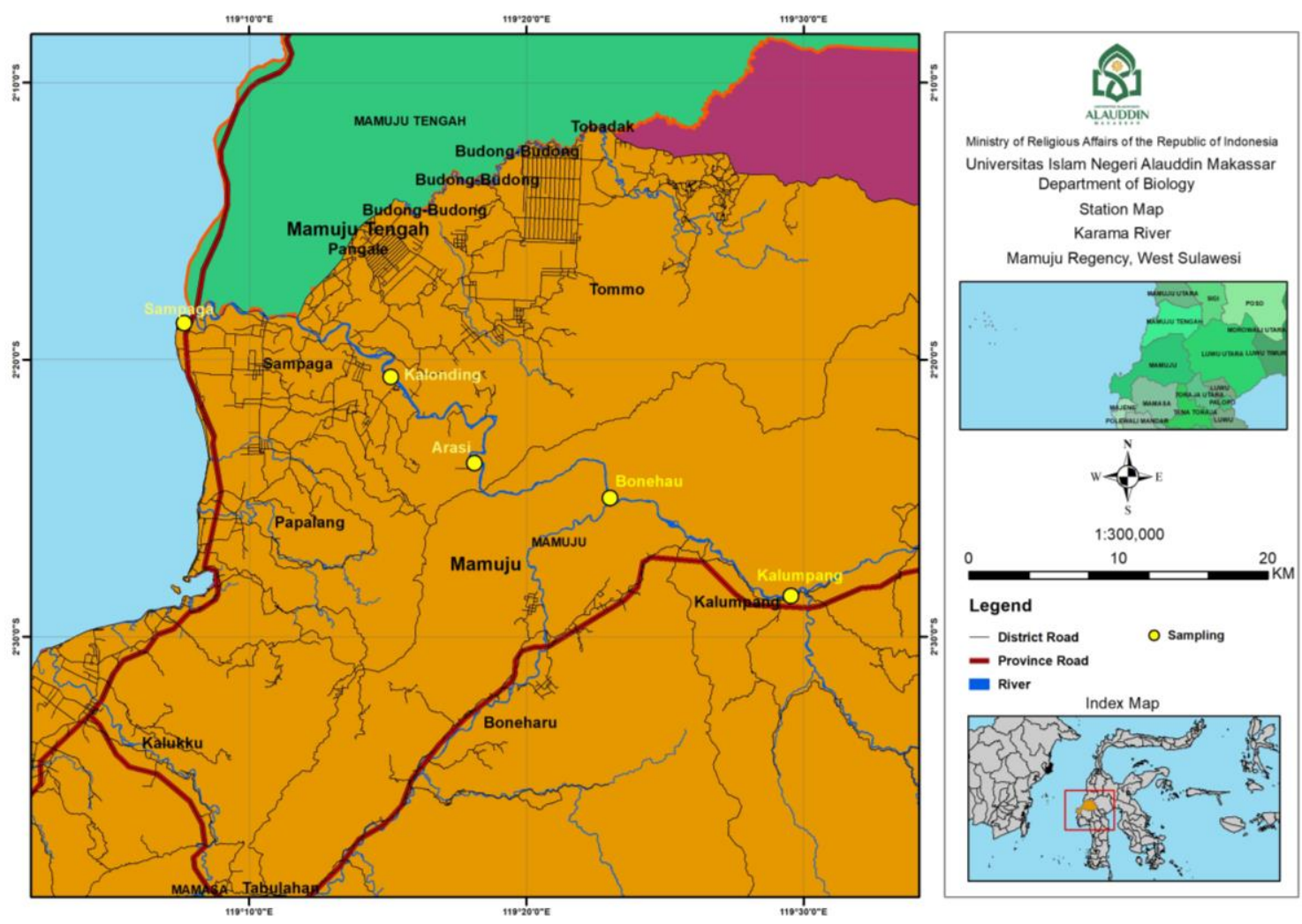

Figure 1. Location of four sampling sites: Kalumpang ( $\left.2^{\circ} 28^{\prime} 10.0^{\prime \prime} \mathrm{S}, 19^{\circ} 29^{\prime} 05.0^{\prime \prime} \mathrm{E}\right)$, Bonehau $\left(2^{\circ} 25^{\prime} 02.0^{\prime \prime} \mathrm{S}, 119^{\circ} 23^{\prime} 01.0^{\prime \prime} \mathrm{E}\right)$, Arassi ( $\left.2^{\circ} 23^{\prime} 11.0^{\prime \prime} \mathrm{S}, 119^{\circ} 18^{\prime} 03.0^{\prime \prime} \mathrm{E}\right)$, and Kalonding $\left(2^{\circ} 20^{\prime} 11.0^{\prime \prime} \mathrm{S}, 119^{\circ} 15^{\prime} 03.0^{\prime \prime} \mathrm{E}\right)$ 
The value of $b$ is used to estimate the growth pattern of the fish which is analyzed whether the value of $b=3$ or the value of $b \neq 3$. If the value of $b=3$ shows an isometric growth pattern, which means that the increase in length is the same as the increase in weight, if the value of $b<3$ shows a negative allometric growth pattern, which means that the length increase is greater than the weight gain and if the value of $b>3$ shows a positive allometric growth pattern which means the increase the weight is greater than the increase in length. The exponent $b$ often has the coefficient a value close to 3 (in isometry), but ranges between 2 and 4 . The value $b=3$ indicates that the fish grows symmetrically or isometrically. Values other than 3 indicate allometric growth. Data analysis was using Microsoft excel.

\section{RESULTS AND DISCUSSION}

The upstream area of Karama is located in Kalumpang village (Kalumpang subdistrict) and the estuary of the river is located in Sampaga village (Sampaga Sub-district) with a long straight line of approximately $\pm 40 \mathrm{~km}$. The upstream section is at an altitude of $\pm 90 \mathrm{~m}$ above sea level. In this study, data for Sampaga station has excluded. At Kalumpang upstream station, we found 19 samples, 15 samples at Bonehau station, 17 samples at Arassi station, and 20 samples at Kalonding station. We identified two species of Sicydiinae, belonging to Genus Sicyopterus: Sicyopterus longifilis and Sicyopterus pugnans.

\section{The external morphology of Sicydiinae Gobiidae Sicyopterus longifilis}

The body shape is fusifom andelongated with whitish brown coloration and seven-eight black bands on the body. The ventral margin of the eye is marked with triangular black to the posterior end of the mouth. Mouth ventrally orientied with lateral cleft of the lip and without median cleft. Dentary with four or seven canine (cone)-like symphyseal teeth on each side. Premaxillary teeth is tricuspid. First dorsal fin is whitish with spines elongate and some black spots on the base. One spine in the second dorsal fin and ten soft rays. Second to fourth rays of dorsal fin are filamentous. Caudal fins are about 1-1.2 mm, has pale to grayish coloration, and are rounded. Anal fin is dark gray with one spine, ten soft rays, and cycloid scales on the base. Pectoral fins are blackish with white bands at the end. Pelvic fins about $0.6 \mathrm{~mm}$ in length translucent and form a strong disk (Figure 2A-H).

\section{Sicyopterus pugnans}

The body shape is fusiform and elongated with brownish orange coloration and six pale black bands on the body. The eye to the posterior end of the mouth is marked with pale bands. Mouth ventrally oriented with lateral cleft of the lip and without median cleft. Dentary has two or four canine (cone)-like symphyseal teeth on each side. Premaxillary teeth are bicuspid. First dorsal fin is whitish with spines elongated and without black spots on the base.
One spine is in the second dorsal fin with ten soft rays. Caudal fins are about $0.7-1 \mathrm{~mm}$ in lenght, pale orange, and rounded. Anal fin is pale orange to grayish with one spine and ten soft rays. Cup-like disk is attached to belly. Pectoral fins are pale gray with vague blotchings. Pelvic fins, forming a disk, are about $0.4-0.7 \mathrm{~mm}$ in length and translucent (Figure 3A-H).

\section{Habitat characteristics of Sicydiinae Gobiidae}

Sandy and rocky substrate is the habitat preference of Sicydiinae Gobiidae in Karama River, in addition to other environmental characteristics that are also interrelated. Data about the characteristics of the habitat and abiotic parameters shown in Table 1.

\section{Length-weight relationship and growth pattern of Sicydiinae Gobiidae}

A total of 71 individual adult Sicydiinae Gobiidae found at four sites were dominated by $87 \%$ S. longifilis while S. pugnans was only around $13 \%$. Distribution and results of lenght-weigh relationships are presented in Table 2.

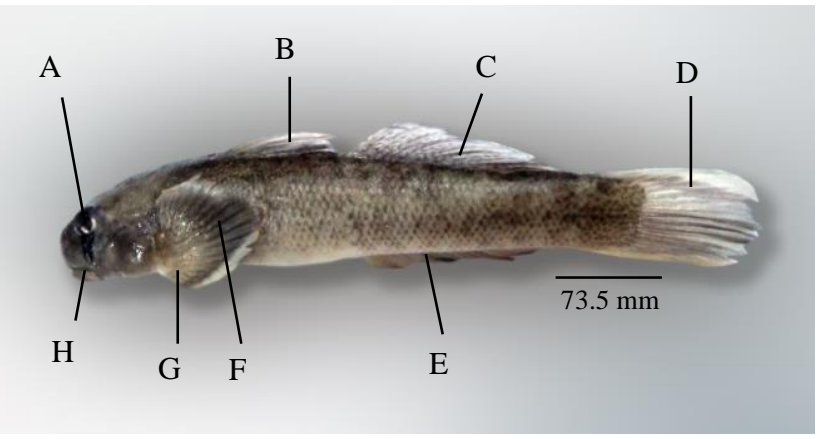

Figure 2. Morphology of Sicyopterus longifilis found in Karama River. A: Eye; B: spiny dorsal fin; C: soft dorsal fin; D: caudal fin; $\mathrm{E}$ : anal fin; F: pectoral fin; G: pelvic fin; $\mathrm{H}$ : mouth

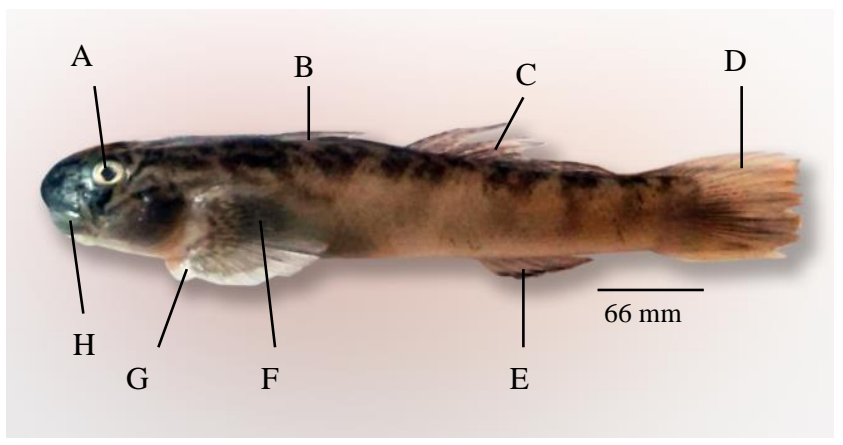

Figure 3. Morphology of Sicyopterus pugnans found in Karama River. A: Eye; B: spiny dorsal fin; C: soft dorsal fin; D: caudal fin; E: anal fin; F: pectoral fin; G: pelvic fin; H: mouth 
Table 1. Characteristics of Sicydiinae Gobiidae fish habitat in four sites in Karama River, West Sulawesi, Indonesia

\begin{tabular}{lcccc}
\hline \multirow{2}{*}{ Characters of habitat } & \multicolumn{2}{c}{ Site } & Arassi & Kalonding \\
\cline { 2 - 5 } & Kalumpang (upstream) & Bonehau & 31 & 20 \\
\hline Altitude (m a.s.l.) & 88 & 44 & 7.2 & 7.9 \\
pH & 7.5 & 7.8 & 25 & 25 \\
Temperature $\left({ }^{\circ} \mathrm{C}\right)$ & 23 & 24 & 7.8 & 7.5 \\
DO $(\mathrm{mg} / \mathrm{L})$ & 8.1 & 7.9 & 0.22 & 0.23 \\
Brightness $(\mathrm{m})$ & 0.32 & 140 & 160 & 0 \\
Velocity $\left(\mathrm{cm} . \mathrm{s}^{-1}\right)$ & 20 & 0 & 0 & 0.19 \\
Salinity $(\mathrm{ppt})$ & 0 & 0.23 & 0.19 & 0.17 \\
Depth $(\mathrm{m})$ & 0.46 & small rocks, sand & small rocks, sand & small rock, sand \\
Substrate & large rocks, slightly, sandy & & & \\
\hline
\end{tabular}

Table 2. Estimated parameters for length-weight relationships in S. longifilis and S. pugnans in four sample sites

\begin{tabular}{llclcc}
\hline \multicolumn{1}{c}{ Site } & \multicolumn{1}{c}{ Species } & n & \multicolumn{1}{c}{ Growth pattern } & Wr & K \\
\hline Kalumpang & Sicyopterus longifilis & 13 & Isometric $(b=3.003)$ & 0.960 & 1.997 \\
& Sicyopterus pugnans & 6 & positive allometric $(b=3.457)$ & 0.936 & 1.899 \\
Bonehau & Sicyopterus longifilis & 15 & negative allometric $(b=2.610)$ & 0.895 & 1.974 \\
Arassi & Sicyopterus longifilis & 17 & negative allometric $(b=2.888)$ & 0.817 & 2.134 \\
Kalonding & Sicyopterus longifilis & 17 & negative allometric $(b=2.468)$ & 0.855 & 2.282 \\
& Sicyopterus pugnans & 3 & negative allometric $(b=-0.25)$ & 0.007 & 2.196 \\
\hline
\end{tabular}

Note: $\mathrm{n}=$ total of individual; $\mathrm{Wr}=$ weight relative $(\mathrm{g}) ; \mathrm{K}=$ condition factor; $\mathrm{a} \& \mathrm{~b}=$ regression coefficient and exponent; where $\mathrm{Ws}=$ $a L T^{b}$
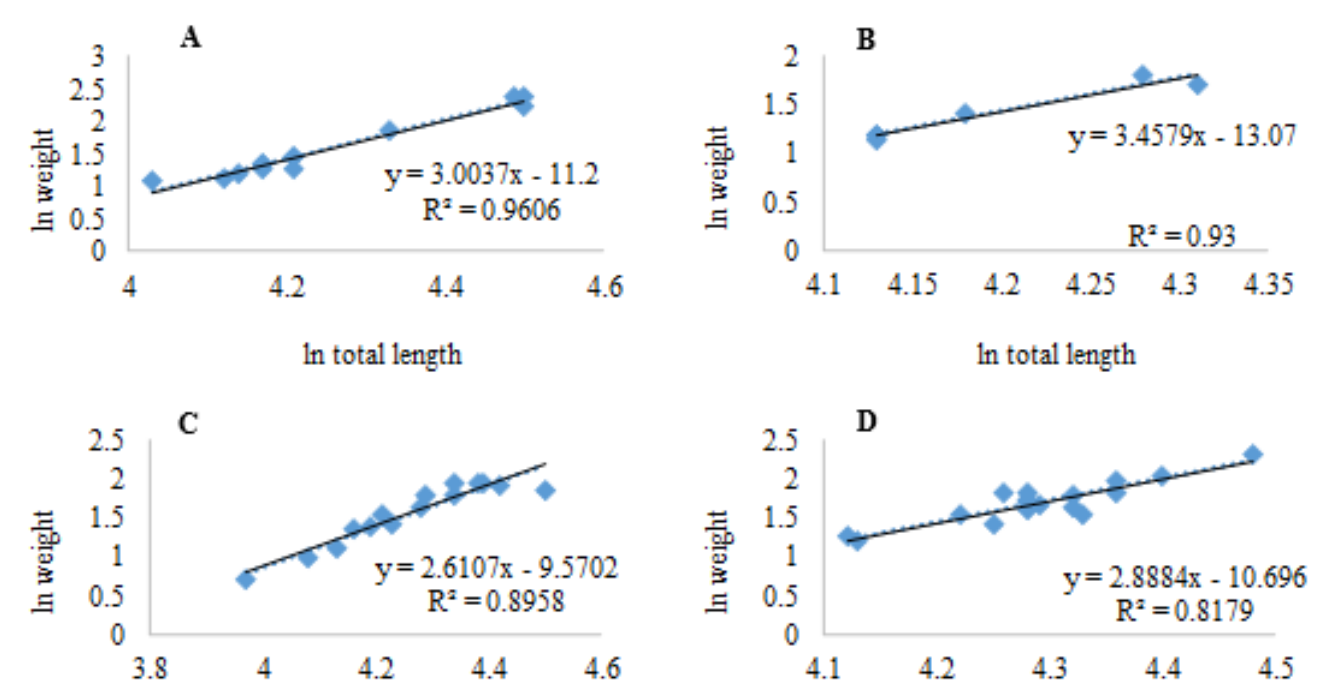

In total length

In total length
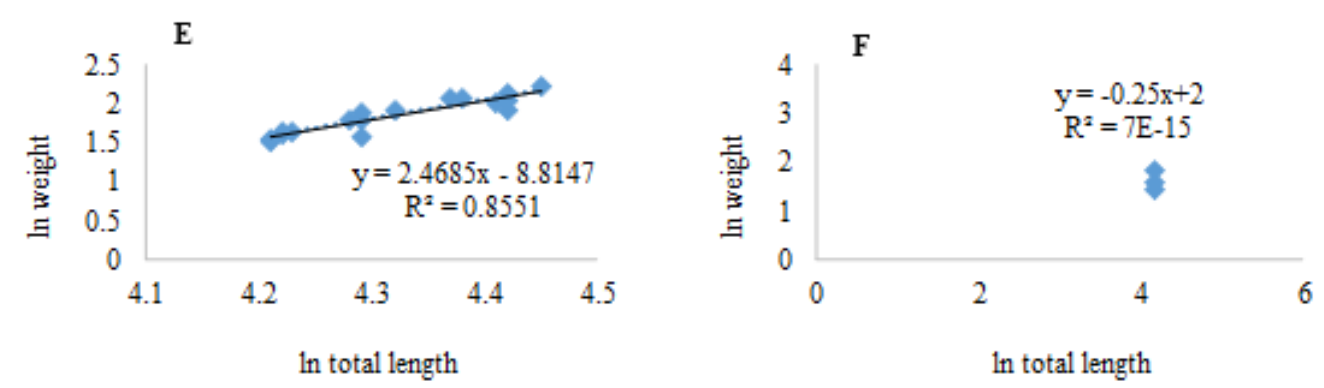

Figure 4. Relationship between total length and weight of Sicyopterus collected from Kalumpang station. A: S. longifilis; B: S. pugnans; C: Bonehau station (S. longifilis); D: Arassi station (S. pugnans); E: Kalonding station (S. longifilis); F: S. pugnans 
Prior to this study, reports and notes regarding the presence and distribution of this genus are still unclear in four sites. The total number of fish from four sites is about 71 adult Gobiidae fish, where $S$. longifilis was found in all sites, whole of 62 samples, nevertheless S. pugnans was found nine in total at Kalumpang and Kalonding only.. The value of $b$ is then used to estimate the growth pattern of the fish analyzed whether $b=3$ or $b \neq 3$. The scatter plot reflects the exponential growth in weight with increasing length, shown in Figure 4.

\section{Discussion}

The description of body shape and morphological structure of Goby fish becomes a vital basis in precise taxonomy and systematic process, with some additional ecological dataset, distribution, growth pattern, and other supporting data. The latest identification data is continuously added to meet the stabilized of a particular genus. Misidentification is inevitable even when the genus taxonomy has sufficiently detailed. Maeda and Saeki (2018) conducted a revision of de Beaufort (1912) with genus Sicyopterus' description according to their findings in Japan. New records of this genus continues to grow in Indonesia, particularly in Sulawesi. Penja fish was found by Nur et al. (2018) in Karema River, West Sulawesi, but the genus has not been identified. Gani et al. (2019) found Sicyopterus lagocephalus and S. longifilis in Biak and Koyoan River, Central Sulawesi. S. longifilis and $S$. pugnans were also identified by Olii et al. (2019) in Gorontalo Bay and Bone River, Gorontalo waters. A total of 96 individuals of Sicyopterus species found by Nurjirana et al. (2019), including Sicyopterus lagocephalus, S. longifilis, and Sicyopus zosterophorum in Leppangan River, West Sulawesi. We identified morphological variations in two species of Sicyopterus, sustaining the presence of this genus in Karama River.

The morphology of $S$. longifilis in Karama River (Figure 2) has a different color with $S$. longifilis described by Gani et al. (2019) in Biak River. The body coloration is dominated by brown in $S$. longifilis in Karama River, which is reported to be similar to S. longifilis from Japan (Maeda and Saeki 2018), while S. longifilis in Biak River is dominated by blue. Black triangular bar was located below the eye. Median cleft at upper lip was not found as Maeda and Saeki (2018) reported in contrast with de Beaufort (1912). Dorsal fin, caudal fins, anal fins, pectoral fins and pelvic fins are similar to characteristics described by Keith et al. (2015). The morphology of $S$. pugnans have in common with $S$. longifilis, except in following cases, the body color, pectoral fin of $S$. pugnans has a pale gray, whereas in $S$. longifilis is black with white bands, $S$. longifilis showed dorsal fin with black mottling on body three fourth, while in S. pugnan only on body top and sides (Figure 3).

In general, the value of $b$ depends on the physiological and environmental conditions (Mir et al. 2012; Jisr et al. 2018) such as temperature, climate change, $\mathrm{pH}$, conductivity, salinity, dissolved oxygen, geographical location, and sampling techniques (Pankhurst and Munday
2011; Elboray et al. 2012; Nehemia et al. 2012; Davies et al. 2013; Muchlisin et al. 2015; Makori et al. 2017; Sánchez-González et al. 2020) as well as biological factors, for instance, gonadal development and food availability (Ighwela et al. 2011; Hossain et al. 2012; Luin et al. 2013; Akombo et al. 2014). The station's altitude on Karama River reaches 20-88 m above sea level from Sampaga estuary to the upstream of Kalumpang (Table 1). This indicates that Sicyopterus can migrate upstream even though its elevation reaches high above sea level $(<100 \mathrm{~m})$. In line with this, Teichert et al. (2013) caught Sicyopterus species downstream stations $(<100 \mathrm{~m})$ on perennial rivers of Reunion Island. In addition, the presence of Sicyopterus species also provided by Ebner et al. (2011) at at highest densitiy with an elevation of approximately 10-50 m above sea level in Noah Creek and Pauls Pocket Creek.

Rocky substrate mixed with sand is habitat preference of Sicyopterus species in Karama River. Rocky surfaces are a growing medium for diatoms and algae, beside the benthic surface. Algae and diatoms as the main source of food scrapped by adults using rake-like of upper jaw premaxillary teeth (Lord et al. 2012; Cullen et al. 2013; Sahara et al. 2016). The rocky substrate also offering hiding spots (Lord et al. 2012; Barbeyron et al. 2017), safe place for large number of small eggs (Teichert et al. 2013; Ellien et al. 2016), and also as climbing surface using their oral and pelvic sucker with an inching behavior (Blob et al. 2013; Cullen et al. 2013; Christy and Maie 2019).

The average growth pattern in all sites is negative allometric $(b<3)$, except in the Kalumpang sites, growth pattern for $S$. longifilis is isometric $(b=3)$ whereas in $S$. pugnans fish in the station Kalumpang growth pattern is positive allometric (b>3). This implies that $S$. longifilis and $S$. pugnans generally in Karama River become longer, thus making them more slender. The body proportion of these fish in grams is below the increase in total length, which is measured from the tip of snout to the tip of caudal fin (Figure 4). Compared with the findings of Nur et al. (2018), negative allometric growth was also measured on Penja fish in Karema River. Although the total length range is shorter in comparison Sicyopterus in Karama River. The growth pattern varies and changeable according to specific environmental, biological factors, and trophic levels (Freitas et al. 2017; Saberi et al. 2017). The negative allometric pattern in this study may be attributed to the adaptation effort of Sicyopterus toward the site's condition. The slender body will make easiness to hide in the substrate gap from predator attacks, like a fish-eating bird, crab, and shrimp. There is allometric relation between fish body size and water-flow velocity (Hockley et al. 2014; Del Signore et al. 2016) which interpreted the slender body of Sicyopterus will help to improve the swimming velocity and swimming ability through the rocky substrate. Based on water-flow velocity, four sites on Karama River are classified as low $\left(10-25 \mathrm{~cm} . \mathrm{s}^{-1}\right)$ to high $\left(>100 \mathrm{~cm} \cdot \mathrm{s}^{-1}\right)$ current velocities, respectively; 20, 140, 160, and 80. Low current velocity has an indirect effect on food availability (García et al. 2011; Kemp et al. 2011; Mims et al. 2012) at composition assembly in diatoms. Silica and other organic 
matters as the energy source for diatoms found in sand and rock powder can be deposited longer. There are no tidal currents and pressure waves to carry them. In addition, low current velocity may be attributed as a direct effect on aquatic substrate formation in Kalumpang upstream. $S$. longifilis showed a single distribution in two sites in Karama River towards high-flow. This result is similar to the findings reported by Donaldson et al. (2013) that $S$. lagocephalus in Australian wet tropics is one species possible to reach extremely high-flow while incapable of other species.

Condition factors were calculated to assess fish health generally, productivity, and physiological conditions of fish populations (Dalu et al. 2013; Van Beveren et al. 2014; Lederoun et al. 2016). This condition factor reflects the body's morphological characteristics growth rate (Enberg et al. 2012; Ara et al. 2014; Killen et al. 2016). The value of condition factors owned by each fish is expected to have high enough fecundity as a fish adaptation to maintain its population in nature.

The range of condition from the data analysis factor is 1.89-2.28 (Tabel 2), whereas if more $>2$ then dominated by fish with maturity level of gonad (Esmaeili et al. 2017; Masoomizadeh et al. 2018; Famoofo and Abdul 2020) while weight value observed in each species per station is low and high compared to the predicted weight. This value indicates that there are areas of poor water conditions to support growth, but the value of the condition factor gives an average value above 100 . The waters in Karama river provide enough food or low predator density here, but for self-adjusting organisms will grow and reproduce.

In conclucion, adult Gobiidae fish identified as $S$. longifilis and $S$. pugnans found in four sites from Karama River. The average growth pattern in all sites is isometric negative, except in the Kalumpang sites, growth pattern for S. longifilis is isometric, while $S$. pugnans shows positive allometric.

\section{REFERENCES}

Akombo PM, Akange ET, Adikwu IA, Araoye PA. 2014. Length-weigh relationship, condition factor and feeding habits of Synodontis schall (Bloch and Schneider, 1801) in river Benue at Makurdi, Nigeria. Int J Fish Aquat Stud 1 (3): 42-48

Ara MG, Nobi MN, Fatema MK, Ahmed ZF. 2014. Evaluation of condition factor of a small indigenous freshwater prawn, Macrobrachium lamarrei (H. Milne-Edwards, 1837) in Bangladesh. Int J Nat Soc Sci 1 (12): 71-76.

Artzrouni M, Teichert N, Mara T. 2014. A Leslie matrix model for Sicyopterus lagocephalus in La Réunion: Sensitivity, uncertainty and research prioritization. Math Biosci 256: 18-27. DOI: 10.1016/j.mbs.2014.08.005.

Barbeyron C, Lefrancois E, Monti D, Keith P, Lord C. 2017. Gardening behaviour of Sicydium punctatum (Gobioidei: Sicydiinae): In vitro experiments in the context of chlordecone pollution in Guadeloupe Island rivers. Cybium 41 (2): 85-92.

Bauer RT. 2013. Amphidromy in shrimps: A life cycle between rivers and the sea. Lat Am J Aquat Res 41 (4): 633-650. DOI: 103856/vol41issue4-fulltext-2.

Bhaumik U, Shrivastava NP, Satpathy BB, Mukhopadhyay MK, Sharma AP. 2011. Impact of hydro-ecology on fish migration in selected east coast estuaries. J Inland Fish Soc India 43: 1-9. DOI: 10.3389/fmars.2019.00237.
Blob RW, Cullen J, Maie T, Schoenfuss HL. 2013. Evolutionary novelty versus exaptation: Oral kinematicsin feeding versus climbing in the waterfall-climbing Hawaiian Goby Sicyopterus stimpsoni. PLoS One 8: 1-10. DOI: 10.1371/journal.pone.0053274.

Boseto DT, Magnuson SJF, Pezold FL. 2016. Population genetic structure of the goby Stiphodon rutilaureus (Gobiidae) in the New Georgia Group, Solomon Islands. Pac Conserv Biol 22 (3): 281-291. DOI: $10.1071 / \mathrm{PC} 14934$.

Christoffersen M, Svendsen JC, Behrens JW, Jepsen N, van Deurs M. 2019. Using acoustic telemetry and snorkel surveys to study diel activity and seasonal migration of round goby (Neogobius melanostomus) in an estuary of the Western Baltic Sea. Fisheries Manag Ecol 26 (2): 172-182. DOI: 10.1111/fme.12336.

Christy RM, Maie T. 2019. Adhesive force and endurance during waterfall climbing in an amphidromous gobiid, Sicyopterus japonicus (Teleostei: Gobiidae): Ontogenetic scaling of novel locomotor performance. Zool 133: 10-16. DOI: 10.1016/j.zool.2019.02.001

Cloern JE. 2018. Why large cells dominate estuarine phytoplankton. Limnol Oceanogr 63: 392-409. DOI: 10.1002/lno.10749

Cullen JA, Maie T, Schoenfuss HL, Blob RW. 2013. Evolutionary novelty versus exaptation: Oral kinematics in feeding versus climbing in the waterfall-climbing Hawaiian goby Sicyopterus stimpsoni. PloS one 8: 1-10. DOI: 10.1371/journal.pone.0053274

Dalu T, Clegg B, Nhiwatiwa T. 2013. Length-weight relationships and condition factors of six fish species caught using gill nets in a tropical African reservoir, Zimbabwe. T Roy Soc S Afr 68 (1): 75-79. DOI: 10.1080/0035919X.2012.733318

Davies OA, Tawari CC, Kwen KI. 2013. Length-Weight Relationship, Condition factor and Sex ratio of Clarias gariepinus juveniles reared in concrete tanks. Int J Environ Sci 1: 324-329. DOI: 10.12983/ijsres2013-p324-329

De Beaufort LF. 1912. On some new Gobiidae from Ceram and Waigen. Zoologischer Anzeiger 39: 136-143.

Del Signore A, Lenders HJR, Hendriks AJ, Vonk JA, Mulder C, Leuven RSEW. 2016. Size-mediated effects of water-flow velocity on riverine fish species. River Res Appl 32 (3): 390-398. DOI: $10.1002 /$ rra.2847.

DeRobert A, William, K. 2008. Weight-legth relationship in fisheries studies: the standard allometric model should be applied with caution. Trans Amer Fish Soc 137: 707-719.

Donaldson JA, Ebner BC, Fulton CJ. 2013. Flow velocity underpins microhabitat selection by gobies of the Australian Wet Tropics. Freshw Biol 58 (5): 1038-1051. DOI: 10.1111/fwb.12107.

Eagderi S, Nasri M, Çiçek E. 2018. First record of the Amur goby Rhinogobius lindbergi Berg 1933 (Gobiidae) from the Tigris River drainage, Iran. Int J Aquat Bio 6 (4): 202-207. DOI: 10.22034/ijab.v6i4.528

Ebner BC, Thuesen PA, Larson HK, Keith P. 2011. A review of distribution, field observations and precautionary conservation requirements for sicydiine gobies in Australia. Cybium 35 (4): 397 414.

Elboray K, EL-Halfawy M, Mahmoud W, Ramadan A, Soliman Y, Amin A. 2012. Growth and gonadal maturation of Keeled mullet, Liza carinata (Valenciennes, 1836) cultured at different salinities. Egypt J Aquat Biol Fish 16 (2): 107-119.

Ellien C, Valade P, Bosmans J, Taillebois L, Teichert N, Keith P. 2011. Influence of salinity on larval development of Sicyopterus lagocephalus (Pallas, 1770) (Gobioidei). Cybium 35 (4): 381-390. DOI: 10.26028/cybium/2011-354-011.

Ellien C, Werner U, Keith P. 2014. Morphological changes during the transition from freshwater to seawater in an amphidromous goby, Sicyopterus lagocephalus (Pallas 1770) (Teleostei). Ecol Freshw Fish 25 (1): 48-59. DOI: 10.1111/eff.12190.

Ellien C, Werner U, Keith, P. 2016. Morphological changes during the transition from freshwater to sea water in an amphidromous goby, Sicyopterus lagocephalus (Pallas 1770) (Teleostei). Ecol Freshw Fish 25 (1): 48-59. DOI: 10.1111/eff.12190.

Enberg K, Jørgensen C, Dunlop ES, Varpe $\varnothing$, Boukal DS, Baulier L, Eliassen S, Heino M. 2012. Fishing-induced evolution of growth: Concepts, mechanisms and the empirical evidence. Mar Ecol 33 (1): 1-25. DOI: 10.1111/j.1439-0485.2011.00460.x.

Esmaeili HR, Choobineh R, Zareian H, Gholamhosseini A. 2017. Life history traits and gonad histology of an endemic cyprinid fish, Mond spotted barb, Capoeta mandica from Southern Iran. J Environ Sci 15 (2): 97-112. 
Famoofo OO, Abdul WO. 2020. Biometry, condition factors and lengthweight relationships of sixteen fish species in Iwopin fresh-water ecotype of Lekki Lagoon, Ogun State, Southwest Nigeria. Heliyon 6 (1): e02957. DOI: 10.1016\%2Fj.heliyon.2019.e02957.

Freitas T, Montag LF, Barthem RB. 2017. Distribution, feeding and ecomorphology of four species of Auchenipteridae (Teleostei: Siluriformes) in Eastern Amazonia, Brazil. Iheringia Ser Zool 107: e2017008. DOI: 10.1590/1678-4766e2017008.

Gani A, Bakri AA, Adriany DT, Nurjirana N, Herjayanto M, Bungalim MI, Ndobe S, Burhanuddin AI. 2019. Identification of freshwater goby species from The Biak and Koyoan Rivers, Luwuk Banggai, Central Sulawesi. Jurnal Ilmu Kelautan Spermonde 5 (2): 57-60.

García A, Jorde K, Habit E, Caamaño D, Parra O. 2011. Downstream environmental effects of dam operations: changes in habitat quality for native fish species. River Res Appl 27: 312-327. DOI: $10.1002 /$ rra.1358.

Greenfield DW, Randall JE. 2010. Eviota karaspila, a new gobiid fish from Fiji. Zootaxa 2672: 61-68.

Hoareau TB, Boissin E, Berrebi P. 2012. Evolutionary history of a widespread Indo-Pacific goby: The role of Pleistocene sea-level changes on demographic contraction/expansion dynamics. Mol Phylogenet Evol 62 (1): 566-572. DOI: 10.1016/j.ympev.2011.10.004

Hockley FA, Wilson CAME, Brew A, Cable J. 2014. Fish responses to flow velocity and turbulence in relation to size, sex and parasite load. J R Soc Interface 11: 20130814. DOI: 10.1098/rsif.2013.0814

Hossain MY, Rahman MM, Fulanda B, Jewel MAS, Ahamed F, Ohtomi J. 2012. Length-weight and length-length relationships of five threatened fish species from the Jamuna (Brahmaputra River tributary) River, northern Bangladesh. J Appl Ichthyol 28 (2): 275 277. DOI: $10.1111 / \mathrm{j} .1439-0426.2011 .01900 . x$

Ighwela KA, Ahmed AB, Abol-Munafi AB. 2011. Condition factor as an indicator of growth and feeding intensity of Nile tilapia fingerlings (Oreochromis niloticus) feed on different levels of maltose. Am Eurasian J Agric Environ Sci 11: 559-563.

Iida M, Watanabe S, Tsukamoto K. 2013. Riverine life history of the amphidromous goby Sicyopterus japonicus (Gobiidae: Sicydiinae). Environ Biol Fishes 96: 645-660.

Iida M, Watanabe S, Tsukamoto K. 2015. Oceanic larval duration and recruitment mechanism of the amphidromous fish Sicyopterus japonicus (Gobioidei: Sicydiinae). Reg Stud Mar Sci 1: 25-33. DOI: 10.1016/j.rsma.2015.03.001.

Jisr N, Younes G, Sukhn C, El-Dakdouki MH. 2018. Length-weight relationships and relative condition factor of fish inhabiting the marine area of the Eastern Mediterranean city, Tripoli-Lebanon. Egypt J Aquat Res 44 (4): 299-305. DOI: 10.1016/j.ejar.2018.11.004.

Kachhi KK, Panhwar SK, Waryani B. 2020. Recent gobies from Pakistan, northern Arabian sea: Diversity and biogeographic affinities. J Appl Ichthyol 36 (2): 183-188. DOI: 10.1111/jai.14007.

Keith P, Hadiaty RK, Busson F, Hubert N. 2014. A new species of Sicyopus (Gobiidae) from Java and Bali. Cybium 38 (3): 173-178. DOI: $10.26028 /$ cybium/2014-383-002.

Keith P, Lord C, Busson F, Sauri S, Hubert N, Hadiaty RK. 2015. A new species of Sicyopterus (Gobiidae) from Indonesia. Cybium 39 (4): 243-248. DOI: 10.26028/cybium/2015-394-001.

Keith P, Marquet G, Taillebois L. 2011. Discovery of the freshwater genus Sicyopus (Teleostei: Gobioidei: Sicydiinae) in Madagascar, with a description of a new species and comments on regional dispersal. J Nat Hist 45 (43-44): 2725-2746. DOI: 10.1080/00222933.2011.602479.

Kemp P, Sear D, Collins A, Naden P, Jones I. 2011. The impacts of fine sediment on riverine fish. Hydrol Process 25 (11): 1800-1821. DOI: 10.1002/hyp.7940.

Killen SS, Glazier DS, Rezende EL, Clark TD, Atkinson D, Willener AS, Halsey LG. 2016. Ecological influences and morphological correlates of resting and maximal metabolic rates across teleost fish species. Am Nat 187 (5): 592-606.

Lederoun D, Lalèyè PA, Vreven EJ, Vandewalle P. 2016. Length-weight and length-length relationships and condition factors of 30 actinopterygian fish from the Mono basin (Benin and Togo, West Africa). Cybium 40 (4): 267-274.

Lord C, Bellec L, Dettaï A, Bonillo C, Keith P. 2019. Does your lip stick? Evolutionary aspects of the mouth morphology of the Indo-Pacific clinging goby of the Sicyopterus genus (Teleostei: Gobioidei: Sicydiinae) based on mitogenome phylogeny. J Zool Syst Evol Res 57 (5): 910-925. DOI: 10.1111/jzs.12291.
Lord C, Lorion J, Dettai A, Watanabe S, Tsukamoto K, Cruaud C, Keith P. 2012. From endemism to widespread distribution: Phylogeography of three amphidromous Sicyopterus species (Teleostei: Gobioidei: Sicydiinae). Mar Ecol Prog Ser 455: 269-285. DOI: 10.3354/meps09617.

Luin M, Fui CF, Senoo S. 2013. Sexual maturation and gonad development in tiger grouper (Epinephelus fuscoguttatus) $\mathrm{x}$ giant grouper (E. lanceolatus) hybrid. J Aquac Res Develop 5: 2. DOI: 10.4172/2155-9546.1000213

Maeda K, Saeki T. 2018. Revision of species in Sicyopterus (Gobiidae: Sicydiinae) described by de Beaufort (1912), with a First Record of Sicyopterus longifilis from Japan. Species Div 23 (2): 253-262. DOI: 10.12782/specdiv.23.253.

Mahilum JJ, Camama C, Lalisan JA, Vedra SA. 2013. Morphology of goby species, Glossogobius celebius (Valenciennes 1837) and Glossogobius giuris (Hamilton 1822) in Lake Lanao Mindanao, Philippines. Int J Res Biosci 2 (3): 66-78.

Makori AJ, Abuom PO, Kapiyo R, Anyona DN, Dida GO. 2017. Effects of water physico-chemical parameters on tilapia (Oreochromis niloticus) growth in earthen ponds in Teso North Sub-County, Busia County. Fish Aquat Sci 20: 30. DOI: 10.1186/s41240-017-0075-7.

Masoomizadeh SZ, Pazooki J, Valinassab T. 2018. Changes in lengthweight relationship and condition factor of Talang queenfish (Scomberoides commersonnianus) in the north-west Persian Gulf. Iran J Fish Sci 17 (1): 118-136.

Mims MC, Olden JD. 2012. Life history theory predicts fish assemblage response to hydrologic regimes. Ecol 93 (1): 35-45. DOI: 10.1890/110370.1

Mir JI, Sarkar UK, Dwivedi AK, Gusain OP, Pal A, Jena JK. 2012. Pattern of intrabasin variation in condition factor, relative condition factor and form factor of an Indian major carp, Labeo rohita (HamiltonBuchanan, 1822) in the Ganges basin, India. Eur J Biol Sci 4 (4): 126-135. DOI: 10.5829/idosi.ejbs.2012.4.4.6448

Muchlisin ZA, Batubara AS, Azizah MNS, Adlim M, Hendri A, Fadli N, Muhammadar AA, Sugianto S. 2015. Feeding habit and length weight relationship of keureling fish, Tor tambra Valenciennes, 1842 (Cyprinidae) from the western region of Aceh Province, Indonesia. Biodiversitas 16 (1): 89-94. DOI: 10.13057/biodiv/d160112

Muthiadin C, Aziz IR, Andriyani AA. 2017. Awaous melanocephalus: Ikan native species dari Sulawesi Barat (sebuah review). Prosiding Seminar Nasional Biology for Life. Jurusan Biologi UIN Alauddin Makassar, Gowa, 6-10 November 2017. [Indonesian].

Nehemia A, Maganira JD, Rumisha C. 2012. Length-Weight relationship and condition factor of tilapia species grown in marine and fresh water ponds. Agr Biol J N Am 3 (3): 117-124. DOI: 10.5251/abjna.2012.3.3.117.124

Nur M, Omar SBA, Dahlan MA. 2018. Struktur ukuran dan tipe pertumbuhan ikan penja di perairan sungai Karema, Provinsi Sulawesi Barat. Jurnal Saintek Peternakan dan Perikanan 2 (1): 43-47. [Indonesian].

Nurjirana N, Haris A, Sahami FM, Keith P, Burhanuddin AI. 2019. Preliminary note on the morphological characters of penja (amphidromous goby postlarvae) in West Sulawesi and Gorontalo Bay. Proceeding of the 2nd International Symposium on Marine Science and Fisheries (ISMF2). Universitas Hasanuddin, Makassar, 22 June 2019. [Indonesian].

Olii AH, Sahami FM, Hamzah SN, Pasisingi N. 2017. Preliminary findings on distribution pattern of larvae of nike fish (Awaous sp.) in the estuary of Bone River, Gorontalo Province, Indonesia. Aquac Aquar Conserv Legis Bioflux 10 (5): 1110-1118.

Olii AH, Sahami FM, Hamzah SN, Pasisingi N. 2019. Molecular approach to identify gobioid fishes, Nike and Hundala (local name), from Gorontalo Waters, Indonesia. Online J Biol Sci 19 (1): 51-56. DOI: 10.3844/ojbsci.2019.51.56

Pankhurst NW, Munday PL. 2011. Effects of climate change on fish reproduction and early life history stages. Mar Freshw Res 62 (9): 1015-1026. DOI: 10.1071/MF10269

Roche KF, Janač M, Jurajda P. 2013. A review of Gobiid expansion along the Danube-Rhine corridor-geopolitical change as a driver for invasion. Knowl Manag Aquat Ecosyst 411: 1-23. DOI: $10.1051 / \mathrm{kmae} / 2013066$

Rojtinnakorn J, Rittiplang S, Tongsiri S, Chaibu P. 2012. Tumeric extract inducing growth biomarker in sand goby (Oxyeleotris marmoratus). Proceedings of the 2nd International Conference on Chemical, Biological and Environment Sciences (ICCEBS 2012). International 
Academy of Arts, Science and Technology, Bali, 30 June-1 July 2012.

Saberi M, Paighambari SY, Darvishi M, Farkhondeh-Shilsar G. 2017. Length-weight relationships of six fish species from the Coastal Waters of Jask, Iran. J Appl Ichthyol 33 (6): 1226-1228. DOI: 10.1111/jai.13326

Sahara N, Moriyama K, Iida M, Watanabe S. 2016. Time and order of eruption of first functional teeth in the upper jaw of post-larval life of Sicyopterus japonicus (Gobiidiae: Sicydiinae) during cranial metamorphosis at the time of river recruitment. Arch Oral Biol 66: 8 14. DOI: 10.1016/j.archoralbio.2016.02.005

Sánchez-González JR, Arbonés A, Casals F. 2020. Variation over time of length-weight relationships and condition factors for four exotic fish species from a restored shallow lake in NE Iberian Peninsula. Fishes 5 (1): 1-8. DOI: 10.3390/fishes5010007

Shiao JC, Tzeng CS, Li PC, Bell KN. 2015. Upstream migration and marine early life history of amphidromous gobies inferred from otolith increments and microchemistry. Environ Biol Fish 98: $933-$ 950 .

Taillebois L, Maeda K, Vigne S, Keith P. 2012. Pelagic larval duration of three amphidromous Sicydiinae gobies (Teleostei: Gobioidei) including widespread and endemic species. Ecol Freshw Fish 21 (4): 552-559. DOI: 10.1111/j.1600-0633.2012.00575.x
Teichert N, Keith P, Valade P, Richarson M, Metzger M, Gaudin P. 2013. Breeding pattern and nest guarding in Sicyopterus lagocephalus, a widespread amphidromous Gobiidae. J Ethol 31: 239-247.

Teichert N, Valade P, Fostier A, Lagarde R, Gaudin P. 2014. Reproductive biology of an amphidromous goby, Sicyopterus lagocephalus, in La Re'union Island. Hydrobiologia 726: 123-141. DOI: $10.1007 / \mathrm{s} 10750-013-1756-6$

Tran TT, Tran HD, Nguyen HX. 2018. Larval description and habitat utilization of an amphidromous goby, Redigobius bikolanus (Gobiidae). Anim Biol J 68 (1): 15-26. DOI: 10.1163/1570756317000079

Van beveren E, Bonhommeau S, Fromentin JM, Bigot JL, Bourdeix JH, Brosset P, Roos D, Saraux C. 2014. Rapid changes in growth, condition, size and age of small pelagic fish in the Mediterranean. Mar Biol 161: 1809-1822.

Vedra SA, Ocampo PP. 2014. The fishery potential of freshwater gobies in Mandulog River, Northern Mindanao, Philippines. Asian J Agric Dev 11 (1): 1-9. DOI: 10.22004/ag.econ.200295

You J, Yue Y, Xing F, Xia W, Lai S, Zhang F. 2015. Tetrodotoxin poisoning caused by Goby fish consumption in southeast China: A retrospective case series analysis. Clinics 70 (1): 24-29. DOI: $10.6061 /$ clinics/2015(01)05. 